\title{
Hydrolytic enzymes and biodeterioration of groundnut seeds
} R.S. Deshmukh

\author{
Department of Botany, \\ B. Raghunath Arts, Commerce \& Science College, PARBHANI (M.S.) INDIA \\ E-mail : rsdeshmukh19@gmail.com
}

Received : 15.09.2020; Accepted : 10.11.2020

\begin{abstract}
Some common seed borne fungal isolates of Groundnut variety TAG-24 and SB-XI were screened for their ability to produce the hydrolytic enzymes. For this the test seed borne fungal isolates of Groundnut were grown on substrate and nonsubstrate glucose nitrate media for seven days at room temperature. After seven days of incubation the culture filtrates were collected separately and considered them as the crude enzyme preparation. The crude enzyme preparations were assayed by different methods under different conditions. Both varieties of Groundnut Aspergillus terreus and Sclerotium rolfsii were found to be highly amlolytic. All the test isolates of the Groundnut variety TAG-24 and SB-XI produced protease in both the media. Maximum protease production was found by Aspergillus flavus followed by Fusarium oxysporum. All the test isolates produced cellulase in both the media. Maximum cellulase production was found in Sclerotium rolfsii followed by Aspergillus niger and Aspergillus terreus. Among the seven test isolates Aspergillus flavus, Aspergillus terreus, Macrophomina phaseolina could not produce pectinase in the absence of substrate but the production was observed in the presence of substrate.

Figure : 00

References : 08

Table : 00

KEY WORDS : Amylase, Biodeterioration, Cellulase, Groundnut, Pectinase, Protease.
\end{abstract}

\section{Introduction}

Seeds of various crops are known to carry variety of fungi mainly the species of Alternaria, Aspergillus, Curvularia, Chaetomium, Cladosporium, Drechslera, Fusarium, Macrophomina, Mucor, Penicillium, Rhizoctonia, Rhizopus, Syncephalastrum, Torulla, etc. These during their association with seeds in field as well as during storage cause various types of harmful effects to the seeds. The whole process is termed as seed biodeterioration. It is estimated that about $4 \%$ of the world's grains are lost due to biodeteriorations caused by microorganisms ${ }^{1}$.

Micro-organisms exhibit a variety of metabolic activities which are of immense economic importance. They are also better known to destroy food stuff in stored plant materials particularly in food grains. Production of extracellular hydrolytic enzyme by seeds born fungi has a role during the process of seed deterioration and has been considered helpful to their invasion and colonization ${ }^{3}$. Therefore production of hydrolytic enzymes by seed borne fungi and their significance in the seed damage has become prominent aspect for studies on biodeterioration of seeds.

It is clear from the literature that the degree of biodeterioration has been found to be directly related with efficiency of seed moulds to produce hydrolytic enzymes like amlase, protease and lipase.

Therefore some common seed borne fungal isolates of Groundnut variety TAG-24 and SB-XI were screened for their ability to produce the hydrolytic enzymes.

\section{Material and Methods}

Selected seed borne fungi were studied for their ability to produce following hydrolytic enzymes by following methods-

\section{i) AMYLASE}

\section{Production}

Production of Amylase was studied by growing some common and dominant seed borne fungi of Groundnut on liquid medium containing starch $1 \%, \mathrm{KNO}_{3}$ $0.25 \%, \mathrm{KH}_{2} \mathrm{PO}_{4} 0.1 \%$ and $\mathrm{MgSO}_{4}, 7 \mathrm{H}_{2} \mathrm{O} 0.05 \% \mathrm{pH} 5.5^{7}$. Twenty five $\mathrm{ml}$ of the medium was poured in $100 \mathrm{ml}$ Erlenmeyer flask, sterilized for $30 \mathrm{~min}$. at $15 \mathrm{lbs}$ and inoculated separately with one $\mathrm{ml}$ spore/mycelial suspension of test fungus (grown for seven days on PDA). The flasks were incubated for 6 days at $23^{\circ} \mathrm{C} \pm 1^{\circ} \mathrm{C}$ with diurnal periodicity of light. Flasks were harvested by filtering through Whatman No.1 filter paper and the filtrates collected in presterilized bottles were termed as crude enzyme preparation. 
Constitutive enzyme production was done by substituting starch with glucose $(1 \%)$ in the above medium.

\section{Enzyme assay: (Spectrophotometric assay)}

The assay of amylase was done as described ${ }^{5}$. One $\mathrm{ml}$ of $1 \%$ starch solution in $0.1 \mathrm{M}$ acetate buffer $\mathrm{pH}$ 4.7 mixed with one $\mathrm{ml}$ of enzyme preparation was incubated at room temperature for $15 \mathrm{~min}$. Reaction was stopped by adding $2 \mathrm{ml}$ of dinitrosalicylic acid reagent (DNSA reagent). Mixture was heated in water bath for 5 min. and in warm tube $1 \mathrm{ml} 40 \%$ potassium sodium tartrate solution was added and then cooled in running tap water, $6 \mathrm{ml}$ water was added to make the volume 10 $\mathrm{ml}$ and intensity of colour absorbance was read at 560 $\mathrm{nm}$ in spectrophotometer.

(DNSA reagent:- $1 \mathrm{~g}$ dinitrosalicylic acid $+200 \mathrm{mg}$ Phenol crystals $+50 \mathrm{ml}$ sodium sulphate $+100 \mathrm{ml} 1 \%$ $\mathrm{NaOH}$, stored at $\left.4{ }^{\circ} \mathrm{C}\right)$.

The O.D. values obtained were compared with standard curve prepared with $0-100 \mu \mathrm{g} / \mathrm{ml}$ maltose.

\section{ii) CELLULASES}

\section{Production}

Fungi were grown on liquid medium containing $1 \%$ carboxymethyl cellulose (CMC), $\mathrm{KNO}_{3} 0.25 \%, \mathrm{KH}_{2} \mathrm{PO}_{4}$ $0.1 \%$ and $\mathrm{MgSO}_{4}, 7 \mathrm{H}_{2} \mathrm{O} 0.05 \% \mathrm{pH}$. Rests of the details were same as in case of amylase production.

\section{Enzyme assay: (Spectrophotometric assay)}

The assay was done by following the method ${ }^{2}$. $0.45 \mathrm{ml}$ of $1 \% \mathrm{CMC}$ solution in $0.1 \mathrm{M}$ citrate buffer at 5 $\mathrm{pH}$ was mixed with $0.1 \mathrm{ml}$ of enzyme source and incubated at $55^{\circ} \mathrm{C}$ for $15 \mathrm{~min}$. in water bath, immediately after removing from bath $0.5 \mathrm{ml}$ DNSA reagent was added and mixture heated in boiling water for $5 \mathrm{~min}$. While in the tube warm $1 \mathrm{ml}$ potassium sodium tartrate solution was added. After cooling, water was added to make the volume $5 \mathrm{ml}$. Absorbance was measured at $540 \mathrm{~nm}$ and O.D. recorded. The O.D. values were compared with standard curve prepared with $50 \mu \mathrm{g}$ to $1000 \mu \mathrm{g} / \mathrm{ml}$ glucose.

\section{iii) PECTINASE}

\section{Production}

For the production of pectinase the fungi were grown in a liquid medium composed of pectin $1 \%, \mathrm{KNO}_{3}$ $0.25 \%, \mathrm{KH}_{2} \mathrm{PO}_{4} 0.1 \%$ and $\mathrm{MgSO}_{4}, 7 \mathrm{H}_{2} \mathrm{O} 0.05 \% \mathrm{pH} 5.0$. Further details of the procedure were same as in case of amylase production.

\section{Enzyme assay (Viscometry)}

For this the method ${ }^{4}$ was adopted.

$6 \mathrm{ml}$ of $0.75 \%$ Sodium polypectate in $0.2 \mathrm{M}$ acetate buffer $\mathrm{pH} 5.2,2 \mathrm{ml}$ of $0.2 \mathrm{M}$ acetate buffer $\mathrm{pH} 5.2$ and 4 $\mathrm{ml}$ of enzyme source were taken in 300 Ostwald viscometer and were thoroughly mixed and incubated at $35{ }^{\circ} \mathrm{C}$ temperature. The efflux time of the mixture at various intervals recorded and percent loss of viscosity was calculated as follows-

$\%$ loss of viscosity $=\frac{T_{0}-T_{x}}{T_{0}-T_{w}} \times 100$

Where $T_{0}=$ Flow time in seconds at zero time.

$\mathrm{T}_{\mathrm{x}}=$ Flow time of the reaction mixture at time $\mathrm{T}$.

$\mathrm{T}_{\mathrm{w}}=$ Flow time of distilled water.

The enzyme activity is expressed in relative viscosity units

$$
(R V U)=\frac{1000}{t v-50}
$$

Where tv- 50 is the time required for $50 \%$ loss of viscosity of the reaction mixture.

\section{iv) PROTEASE}

\section{Production}

The production of protease in the fungi was studied by growing them on liquid medium containing casein hydrolysate $5 \%$, glucose $1 \%, 0.1 \% \mathrm{KH}_{2} \mathrm{PO}_{4}$ and $\mathrm{MgSO}_{4} \cdot 7 \mathrm{H}_{2} \mathrm{O} 0.05 \%, \mathrm{pH}$ 5.6. Further details of obtaining crude enzyme preparation were same as in case of amylase.

\section{Enzyme assay (Cup plate method)}

The assay of protease was done by using the method $^{6}$. The basal medium was composed of $4 \%$ gelatin in nutrient agar (peptone $1 \%$, beef extract $0.3 \%$, agar $2 \%, \mathrm{pH} \mathrm{6.8)}$, medium. $15 \mathrm{ml}$ of the autoclaved medium was poured in presterilized petriplates, on solidification of the medium; a cavity was bored at the centre using a presterilized $8 \mathrm{~mm}$ diameter cork borer. The cavity was filled with $1 \mathrm{ml}$ of enzyme source and incubated for 24 hours at room temperature.

Incubated plates were flooded with $15 \% \mathrm{HgCl}_{2}$ in $7 \mathrm{NHCL}$. A clear zone appeared around the cavity after ten minutes, diameter of the zone was considered proportional to the protease activity while, absence of the zone as no protease activity.

\section{v) LIPASE}

\section{Production}

Lipase production was studied by using liquid medium containing $1 \%$ oil (specific oils used for fungi harvested from respective oilseeds), $\mathrm{KNO}_{3} 0.25 \%$, $\mathrm{KH}_{2} \mathrm{PO}_{4} 0.1 \%$ and $\mathrm{MgSO}_{4}, 7 \mathrm{H}_{2} \mathrm{O} 0.05 \% \mathrm{pH}$ 5.0. Rests of details were same as in case of amylase. Effect of physical factors on lipase production was also studied ${ }^{7}$.

\section{Enzyme assay: (Titration)}

Enzyme assay was worked out as described ${ }^{8}$. 
The reaction mixture contained $2 \mathrm{ml}$ of Glycerol triacetate (Triacetin), $5 \mathrm{ml}$ of $0.2 \mathrm{M}$ citrate phosphate buffer at $\mathrm{pH} 8.0$ and $2 \mathrm{ml}$ of enzyme source, incubated at $36^{\circ} \mathrm{C}$ $\pm 1^{\circ} \mathrm{C}$ for three hours. The reaction was terminated by adding $10 \mathrm{ml}$ of absolute alcohol. The amount of acids produced by the activity of enzyme was estimated by titrating against $0.05 \mathrm{~N} \mathrm{NaOH}$ using $1 \%$ phenolphthalein $(1 \mathrm{ml})$ as an indicator till the development of pink colouration. Reaction mixture soon after the addition of enzyme served the blank. The enzyme activity was expressed in units; one unit is defined as $0.1 \mathrm{ml}$ of 0.05 $\mathrm{N} \mathrm{NaOH}$ required to neutralize the fatty acids liberated during incubation.

\section{Result and Discussion}

For this the test seed borne fungal isolates of Groundnut were grown on substrate and non-substrate glucose nitrate media for seven days at room temperature. After seven days of incubation the culture filtrates were collected separately and considered them as the crude enzyme preparation. The crude enzyme preparations were assayed by different methods under different conditions. The results are presented in Tables- 1 and 2.

It was noticed that in both varieties of Groundnut Aspergillus terreus and Sclerotium rolfsii were found to be highly amlolytic. All the fungi produced amylase in both the substrate and non-substrate medium. On the other hand in the presence of starch only Aspergillus terreus was found suppressed for amylase production.

All the test isolates of the Groundnut variety TAG-
24 and SB-XI produced protease in both the media. Maximum protease production was found by Aspergillus flavus followed by Fusarium oxysporum. Significant stimulation of protease in the presence of substrate was observed in case of Aspergillus flavus, Fusarium oxysporum and Fusarium semitectum.

All the test isolates produced cellulase in both the media. Maximum cellulase production was found in Sclerotium rolfsii followed by Aspergillus niger and Aspergillus terreus. Macrophomina phaseolina and Sclerotium rolfsii produced more cellulase in substrate than in non-substrate medium but this trend was found to be reverse in case of Aspergillus niger and Aspergillus flavus.

Among the seven test isolates Aspergillus flavus, Aspergillus terreus, Macrophomina phaseolina could not produce pectinase in the absence of substrate but the production was observed in the presence of substrate. Maximum production of pectinase was observed in case of Macrophomina phaseolina and minimum in Aspergillus niger.

\section{Conclusion}

It is clear from the results that seed borne fungi of Groundnut showed variation in their capacity to deteriorate the seeds. It is also evident that these seed borne fungi destroyed nutritive value of Groundnut seeds by producing various types of hydrolytic enzymes which is responsible for biodeterioration of seeds.

\section{References}

1. Clerke JH. Fungi in stored products. Pans. 1966. 13:473-481.

2. Denison DA, Koehn RD. Mycologia. 1977. LXIX-592.

3. Dingle J., Reid WW, Solomons GL. The enzyme degradation of pectin and other polysaccharides II. Application of the "cup plate assay" to the estimation of enzyme. J. Sci. Food Agric.1952 4:149-155.

4. Mall S, Suresh K. Enzyme assay. Indian Phytopath. 1988. 4(1): 64-68.

5. Peter Bernfield. Methods of enzymology-Ed. Colowick et al., Aca. Pre. New York. 1955.

6. Rao K, Mukharji D. Some metabolic changes during development and senescence in leaves of Cajanus. J. Ind. Bot. Soc. 1990. 69: 311-374.

7. Umatlae MV. Studies on fungal enzymes and toxins in biodeterioration of oil seeds. Ph.D. Thesis, Dr. Babasaheb Ambedkar Marathwada University, Aurangabad , India.1995. pp-142-144.

8. Ure KM, Balas GS, Bhatia DS. Science and Culture. 1962. 28: 581. 